\title{
Review of Tool Condition Monitoring Methods
}

\author{
Ramesh Visariya \\ K.J Somaiya College of \\ Engineering, Vidyavihar, \\ Mumbai
}

\author{
Ronak Ruparel \\ K.J Somaiya College of \\ Engineering, Vidyavihar, \\ Mumbai
}

\author{
Rahul Yadav \\ K.J Somaiya College of \\ Engineering, Vidyavihar, \\ Mumbai
}

\begin{abstract}
With the increase of modern industries use of metal cutting procedure, it is evident that the tools used for this processes required proper care and monitoring. Tool wear one of the most important factors in machining processes as it greatly affects the tool life, which is important in metal cutting because of its direct impact on the quality of the finished job and also affect the efficiency of industries. Hence, ways to observe cutting tool and monitor its wear are needed for optimal use. An effective system can reduce machine downtime and economic losses. The paper presents a overview of many Tool Condition Monitoring Systems.
\end{abstract}

\section{General Terms}

Tool Condition Monitoring, Review, Sensors.

\section{Keywords}

Decision Making Systems, Condition Monitoring, Neural Networks.

\section{INTRODUCTION}

Manufacturing processes must not undergo interruption to achieve complete efficiency [1]. However, degrading process conditions often force manufacturers to disrupt machining processes to respond to degrading production conditions such as tool wear. Thus, developing an effective means of monitoring machine conditions has become one of the most crucial issues in the automation of the process of metal cutting [2]. Among the many possible machining conditions that could be monitored, tool wear is the most critical for ensuring non-disruptive machining. Any effective monitoring system must sense tool state, enable for effective tool change strategies when tools degrade, and maintain appropriate cutting conditions through-out the process [3]. If the monitoring function cannot maintain appropriate cutting conditions, the cutting process could result in poor surface quality, dimensional work piece defects, and even machine defects [2].

Researchers have sought reliable methods to monitor tool wear. A reliable tool wear monitoring system can reduce machine downtime caused by changing the tool, thus leading to fewer process interruptions and higher efficiency. The information obtained from the tool wear sensors can be utilized for several purposes, including the establishment of tool change criteria, economic optimization of the machining operation, influence online process to compensate for tool wear, and, to some extent, the avoiding of catastrophic failure. Tool condition monitoring (TCM) methods can be categorized into many groups based on how they monitor tool conditions. In-process TCM studies detect the quantity of tool wear during the cutting process. Off-process TCM studies find the amount of tool wear at the end of the cutting process. Some studies proposed on-line and off-line systems instead of inprocess and off-process system, but many studies involving "on-line" systems are just describing in-process systems. By definition, on-line systems are executed after the cutting process is finished while in-process systems monitor the tool condition during the cutting process.

TCM systems also may be classified into direct systems and indirect systems, based on the type of sensor technology used. Direct systems gather information from the tool itself. Indirect systems rely on sensors, among which the dynamometer has achieved the greatest correlation with tool conditions. However, the dynamometer is limited because, when it is installed, it may affect the tool capability. In addition, the dynamometer is limited because of its high cost and lack of overload protection [18].

\section{SENSOR TECHNIQUES IN TCM STUDIES}

Various sensors have been explored for TCM and following are types most frequently experimented with. Table 1 gives the summary of these sensor techniques.

\subsection{Optical}

The direct application of the vision sensor for measurement of tool wear utilizes the cutting tool. In general, these sensors rely on the higher reflective properties of the wear and, compared to the unworn surface, to derive various morphological parameters that characterize tool wear. The majority of the research work has pursued only the measurement of flank wear whereas few researchers have attempted to measure both flank and crater wear. Flank wear regions can be imaged with a CCD camera; however, crater wear determination requires the projection of a structured light pattern onto the tool, in order to derive depth information from within the crater [6].

\subsection{Force}

Cutting force measurement is one of the most commonly employed methods for on-line tool wear monitoring, especially in turning because cutting force values are more sensitive to tool wear than other measurements such as vibration or acoustic emission [7]. Use of dynamometer is well established and thus it's relation to tool wear with correct decision making system has been explored countless times. A piezoelectric dynamometer along with data acquisition can be used in neural network to give accurate results [8].Force signals correctly reflect the frictional conditions between cutting tool flank and the work piece. In view of this, [4] described the relationship between flank wear area and cutting forces for turning operations. The experimental results showed that there is an increase in the three directional components of the cutting force with increase in flank wear area.

\subsection{Vibration}

Vibration analysis in tool condition monitoring has been used by many researchers. Researchers used triaxial accelerometer 
to measure vibration signals in three mutually perpendicular directions. Time and frequency domain analysis is carried out to predict tool wear. They observer that vibration signal are most sensitive to tool wear [9]. Others used vibration signals to established the correlation between surface roughness and cutting vibration during turning [10].Some studies developed tool condition monitoring based on tool vibration signals using singular spectrum analysis (SSA) and cluster analysis [11].

\subsection{Acoustic}

Acoustic emissions also have been used in TCM studies. Use of $\mathrm{AE}$ in turning process originates from many sources, such as tool fracture and chipping, chip breakage, friction between the tool and work piece, plastic deformation etc. Thus, it contains information on various tool conditions. Research over the past several years has established the effectiveness of AE-based sensing methodology for various tool condition monitoring tasks [13]. Acoustic Emission sensors in an Automated Sensing and Signal processing Selection system for milling process condition monitoring is described in [12].

\subsection{Multi-sensors}

To overcome the limitations of sensor technologies, several studies have proposed the use of multi-sensors to establish a better correlation between indirect signals and actual condition of tool. Some studies used one dynamometer and accelerometer [14]. A multi-sensor model integrating accelerometer and acoustic emission sensor using fuzzy logic is described in [15]. An alternative example of a multi-sensor system is to study the current signals of feed motor and spindle motor [16] [17]. These studies showed that multisensor systems could provide additional signals for better prediction results.

Table 1. Major sensor techniques in TCM studies

\begin{tabular}{|l|l|l|l|}
\hline Method & Authors & Sensors & Process \\
\hline Optical & $\begin{array}{l}\text { Kurada, } \\
\text { S.,and C. } \\
\text { Bradley }\end{array}$ & CCD and Stylus & Milling \\
\hline Optical & Lanzetta & CCD & Turning \\
\hline Force & $\begin{array}{l}\text { Sikdar } \\
\text { and Chen }\end{array}$ & Dynamometer & Turning \\
\hline Force & $\begin{array}{l}\text { Balazinsk } \\
\text { i,Czogala, } \\
\text { Jemielina } \\
\text { k, } \\
\text { and Leski }\end{array}$ & Dynamometer & Turning \\
\hline Force & $\begin{array}{l}\text { Ozel and } \\
\text { Nadgir }\end{array}$ & Dynamometer & Turning \\
\hline Vibration & $\begin{array}{l}\text { Dimla Sr } \\
\text { DE, } \\
\text { Lister PM }\end{array}$ & Accelerometer & Turning \\
\hline Vibration & $\begin{array}{l}\text { Abouelatt } \\
\text { a OB, } \\
\text { Madl J }\end{array}$ & Accelerometer & Turning \\
\hline $\begin{array}{l}\text { Alonso } \\
\text { FJ, } \\
\text { Salgado } \\
\text { DR }\end{array}$ & Accelerometer & Turning \\
\hline
\end{tabular}

\begin{tabular}{|l|l|l|l|}
\hline Acoustic & $\begin{array}{l}\text { Al- } \\
\text { Habaibeh } \\
\text { and } \\
\text { Gindy }\end{array}$ & $\begin{array}{l}\text { Acoustic } \\
\text { Emission }\end{array}$ & Milling \\
\hline Acoustic & $\begin{array}{l}\text { Niu, } \\
\text { Wong, } \\
\text { Hong, } \\
\text { and Liu }\end{array}$ & $\begin{array}{l}\text { Acoustic } \\
\text { Emission }\end{array}$ & Turning \\
\hline Multi-sensors & $\begin{array}{l}\text { Chen, } \\
\text { Liang } \\
\text { and Y. W. } \\
\text { Jen }\end{array}$ & $\begin{array}{l}\text { Dynamometer } \\
\text { and } \\
\text { Accelerometer }\end{array}$ & Milling \\
\hline Multi-sensors & $\begin{array}{l}\text { Kuo, R.J } \\
\text { Multi-sensors }\end{array}$ & $\begin{array}{l}\text { Dynamometer } \\
\text { and Xiaoli } \\
\text { Emission }\end{array}$ & Turning \\
\hline Current sensor & Turning \\
\hline Multi-sensors & $\begin{array}{l}\text { Stein, } \\
\text { Jeffrey } \\
\text { Lund } \\
\text { Kunsoo } \\
\text { Huh }\end{array}$ & $\begin{array}{l}\text { Current meter } \\
\text { Turning }\end{array}$ & \\
\hline
\end{tabular}

\section{DECISION MAKING SYSTEMS IN TCM STUDIES}

No matter which sensor technology is used, a decisionmaking system that can predict the amount of tool wear is needed for the indirect TCM system. Following are some of the most common TCM decision making systems and they are summarized in Table 2 .

\subsection{Mathematical Model}

Mathematical model can be said to be the oldest used one. Li used the Park and Ulsoy model along with time-series method for signal processing [18]. Besides a wavelet packet transform can be used to extract features in online processing though it is insensitive to various noises and process variations [19]. Tseng and Chou describes another mathematical technique which utilizes the spindle motor parameters and analyses it using load \% [20].

\subsection{Statistical Model}

The statistical model is also an often experimented approach in TCM systems. From systematic experimental data, a relationship functions between the amount of tool wear and signal data is constructed. However, the relationship function developed by the statistical way is often a linear model. Therefore, it is unable to explain non-linearity between dependent and independent variables. These linear statistical models were developed in conjunction with off-process TCM systems. Certain studies used a combination of regression and correlation to arrive at an understanding about the degree of wear [21] [22].

\subsection{Neural Networks}

Artificial Neural Networks (ANN) are the most popular decision making systems employed by far for TCM and they are often combined with other measures to improve accuracy and detail. Unlike statistical or mathematical models, the ANN system can learn from the obtained data and continually change its accuracy. An amalgamation of neural network and regression for tool wear in hard turning is utilized in [23]. It gave better results using Bayesian regularization algorithm. A back propagation approach also gave efficient results as 
mentioned in [8]. A full factorial design and testing used by Samson Lee gave an estimated accuracy of $97 \%$ as mentioned in [5].

\subsection{Fuzzy Logic}

Fuzzy logic is a type of many-valued logic in which the truth values of varying quantities may be any real number between 0 and 1 . It is used to handle the concept of partial truth, where the truth value may range between completely true and completely false. Li summarizes different fuzzy logic approaches in [24]. It explains fuzzy classifiers and also group method of data handling with respect to tool wear monitoring. Signal processing techniques used with this fuzzy systems range from time-series to wavelet transform.

\subsection{Fuzzy Neural Networks}

It is a combination of a neural network with fuzzy logic. The FNN system gains an advantage due to the learning capability of the neural networks and the expert systems of fuzzy logic. As a result, the FNN system displays shorter learning time than systems that use an ANN alone. Error back-propagation and counter propagation have been employed by Kuo in [15]. A centre of gravity part is also present in the method used in [7].

Table 2. Major decision making systems in TCM studies

\begin{tabular}{|c|c|c|c|}
\hline Method & Authors & Schemes & Signal Process \\
\hline Mathematical & Li, Xiaoli & $\begin{array}{l}\text { Park and Ulsoy } \\
\text { model }\end{array}$ & Time-series \\
\hline Mathematical & $\begin{array}{l}\mathrm{Wu}, \mathrm{Ya}, \\
\text { and R.Du }\end{array}$ & $\begin{array}{l}\text { Wavelet packet } \\
\text { feature } \\
\text { extraction }\end{array}$ & WP/FFT \\
\hline Mathematical & $\begin{array}{l}\text { Tseng, P. } \\
\text { C., and A. } \\
\text { Chou }\end{array}$ & Load \% & Time-series \\
\hline Statistical & $\begin{array}{l}\text { Choudhur } \\
\text { y, S.K., } \\
\text { and K.K. } \\
\text { Kishore }\end{array}$ & Correlation & Time-series \\
\hline Statistical & $\begin{array}{l}\text { Davim } \\
\text { and } \\
\text { Baptista }\end{array}$ & Regression & - \\
\hline $\begin{array}{l}\text { Neural } \\
\text { Networks }\end{array}$ & Lee $\mathrm{S}$ & Quick BP & $\begin{array}{l}\text { Wavelet } \\
\text { decomposition. }\end{array}$ \\
\hline $\begin{array}{l}\text { Neural } \\
\text { Networks }\end{array}$ & $\begin{array}{l}\text { Zel, } \\
\text { Tugrul, } \\
\text { and } \\
\text { Abhijit } \\
\text { Nadgir }\end{array}$ & $\mathrm{BP}$ & Time-series \\
\hline $\begin{array}{l}\text { Neural } \\
\text { Networks }\end{array}$ & $\begin{array}{l}\text { Zel, } \\
\text { Turul, } \\
\text { and Yiit } \\
\text { Karpat }\end{array}$ & $\mathrm{BP}$ & WP \\
\hline Fuzzy Logic & Li, Xiaoli & $\begin{array}{l}\text { Fuzzy } \\
\text { Classifier, } \\
\text { Pattern } \\
\text { classification, } \\
\text { Group method } \\
\text { of data } \\
\text { handling(GMD } \\
\text { H), Polynomial } \\
\text { Learning }\end{array}$ & $\begin{array}{l}\text { Time-series, } \\
\text { Fourier } \\
\text { Transform, } \\
\text { Short time } \\
\text { Fourier } \\
\text { transform, } \\
\text { wavelet } \\
\text { transform }\end{array}$ \\
\hline
\end{tabular}

\begin{tabular}{|l|l|l|l|}
\hline & & $\begin{array}{l}\text { Network(PLN), } \\
\text { BP }\end{array}$ & \\
\hline $\begin{array}{l}\text { Fuzzy Neural } \\
\text { Networks }\end{array}$ & $\begin{array}{l}\text { Balazinsk } \\
\text { i, Marek, } \\
\text { et al }\end{array}$ & $\begin{array}{l}\text { Center of } \\
\text { Gravity, BP }\end{array}$ & Time-series \\
\hline $\begin{array}{l}\text { Fuzzy Neural } \\
\text { Networks }\end{array}$ & Kuo, R.J. & $\begin{array}{l}\text { Error-back } \\
\text { propagation, } \\
\text { counter- } \\
\text { propagation }\end{array}$ & $\begin{array}{l}\text { Time-series, } \\
\text { FFT }\end{array}$ \\
\hline
\end{tabular}

\section{CONCLUSION}

Thus, we studied various Tool Condition Monitoring techniques with sensor types and decision making systems as the basis. Further a summary of evolution of these techniques could be observed in tables 1 and 2 . The summary of the tables suggest the evolution of various sensor technologies from single parameter sensing via one or two sensors to a combined study using multi-sensors. Also the maturity of decision making systems from simple statistical to complex neural networks and fuzzy logic is evident.

\section{ACKNOWLEDGMENTS}

Special thanks to following for their guidance and contributions in making this research possible.

1) Sheetal Pereira, Assistant Professor, Department of Computer Engineering, KJSCE,

Email-id: sheetalpereira@somaiya.edu

2) Krish Thakkar, Student, Department of Computer Engineering, KJSCE,

Email-id: krish.thakkar@somaiya.edu

\section{REFERENCES}

[1] Venkatesh, K., Zhou, M., \& Caudill, R.J. Design of artificial neural networks for tool wear monitoring. Journal of Intelligent Manufacturing, 8(3), 1997, pp. 215-226.

[2] Li, X., Dong, S., \& Venuvinod, P.K. Hybrid learning or tool wear monitoring. International Journal of Advanced Manufacturing Technology, 16, 2000, pp.303- 307.

[3] Lee, J.H., Kim, D.E., \& Lee, S.J. Statistical analysis of cutting force ratios for flank-wear monitoring. Journal of Materials Processing Technology, 74, 1998, pp. 104-114.

[4] S. K. Sikdar, M. Chen, Relationship between tool flank wear area and component forces in single point turning, Journal of Materials Processing Technology 128 (2002) 210215 .

[5] Lee S (2010) Tool condition monitoring system in turning operation utilizing wavelet signal processing and multi-learning ANNs algorithm methodology. Int J Eng Res Innov 49.

[6] Kurada, S., and C. Bradley. "A review of machine vision sensors for tool condition monitoring." Computers in industry 34.1 (1997): 55-72.

[7] Balazinski, Marek, et al. "Tool condition monitoring using artificial intelligence methods." Engineering Applications of Artificial Intelligence 15.1 (2002): 7380.

[8] Zel, Tugrul, and Abhijit Nadgir. "Prediction of flank wear by using back propagation neural network modeling when cutting hardened $\mathrm{H}-13$ steel with 
chamfered and honed CBN tools." International Journal of Machine Tools and Manufacture 42.2 (2002): 287297.

[9] Dimla Sr DE, Lister PM. On-line metal cutting tool condition monitoring. I: force and vibration analyses, International Journal of Machine Tools and Manufacture 2000; 40:739768.

[10] Abouelatta OB, Madl J. Surface roughness prediction based on cutting parameter and tool vibration in turning operation. Journal of material processing technology 2001; 118:269-277.

[11] Alonso FJ, Salgado DR, Analysis of the structure of vibration signals for tool wear detection. Mechanical Systems and Signal Processing 2008; 22:735748.

[12] Al-Habaibeh, A., and N. Gindy. "A new approach for systematic design of condition monitoring systems for milling processes." Journal of Materials Processing Technology 107.1-3 (2000): 243-251.

[13] Niu, Y. M., et al."Multi-category classification of tool conditions using wavelet packets and ART2 network." Journal of manufacturing science and engineering 120.4 (1998): 807-816.

[14] Chen, Shang-Liang, and Y. W. Jen. "Data fusion neural network for tool condition monitoring in $\mathrm{CNC}$ milling machining." International journal of machine tools and manufacture 40.3 (2000): 381-400.

[15] Kuo, R. J. "Multi-sensor integration for on-line tool wear estimation through artificial neural networks and fuzzy neural network." Engineering Applications of Artificial Intelligence 13.3 (2000): 249-261.

[16] Li, Xiaoli. "Detection of tool flute breakage in end milling using feed-motor current signatures." IEEE/ASME transactions on mechatronics 6.4 (2001): 491-498.
[17] Stein, Jeffrey L., and Kunsoo Huh. "Monitoring cutting forces in turning: a model-based approach." Journal of Manufacturing science and engineering 124.1 (2002): 26-31.

[18] Li, Xiaoli. "Real-time tool wear condition monitoring in turning." International Journal of Production Research 39.5 (2001): 981-992.

[19] Wu, Ya, and R. Du. "Feature extraction and assessment using wavelet packets for monitoring of machining processes." Mechanical systems and signal processing 10.1 (1996): 29-53.

[20] Tseng, P. C., and A. Chou. "The intelligent on-line monitoring of end milling." International Journal of Machine Tools and Manufacture 42.1 (2002): 89-97.

[21] Choudhury, S. K., and K. K. Kishore. "Tool wear measurement in turning using force ratio." International Journal of Machine Tools and Manufacture 40.6 (2000): 899-909.

[22] Davim, J.P., and Baptista, A.M. (2000). Relationship between cutting force and PCD cutting tool wear in machining silicon carbide reinforced aluminum. Journal of Materials Processing Technology, 103, 417-423.

[23] Zel, Turul, and Yiit Karpat. "Predictive modeling of surface roughness and tool wear in hard turning using regression and neural networks." International Journal of Machine Tools and Manufacture 45.4-5 (2005): 467-479.

[24] Li, Xiaoli. "A brief review: acoustic emission method for tool wear monitoring during turning." International Journal of Machine Tools and Manufacture 42.2 (2002): 157-165. 